\title{
ANALISIS JUMLAH SUDU MANGKUK TERHADAP KINERJA TURBIN PELTON PADA ALAT PRAKTIKUM TURBIN AIR
}

\author{
Ahmad Yani'1, Budi Susanto ${ }^{2}$, Rosmiati ${ }^{3}$ \\ Jurusan Teknik Mesin Sekolah Tinggi Teknologi Industri Bontang ${ }^{1}$ \\ JI. Brigjen Katamso No. 40 Bontang - Kaltim \\ Jurusan Teknik Mesin Fakultas Teknik Universitas Trunajaya Bontang ${ }^{2,3}$ \\ Jl. Taekwondo No. 55 Bontang - Kaltim 75311 \\ Email: yanibima@gmail.com¹; budisusanto8@gmail.com²; Hanafi.rosmiati@gmail.com³
}

\begin{abstract}
Abstrak
Energi air dapat dimanfaatkan sebagai pembangkit listrik dengan memanfaatkan tenaga potensial yang tersedia (potensi air terjun dan kecepatan aliran). Turbin air merupakan salah satu mesin penggerak yang mana fluida kerjanya adalah air yang dipergunakan langsung untuk memutarkan runner turbin dan generator turbin sehingga menghasilkan energi listrik. Penelitian ini dilakukan dengan menggunakan instalasi turbin air jenis pelton dan dilakukan pengukuran terhadap putaran turbin dan generator, debit aliran, head turbin, tegangan listrik dan arus listrik dengan variasi jumlah sudu mangkuk. Metode penelitian yang digunakan adalah metode eksperimen berskala laboratorium sekaligus hasil rancang bangun turbin air ini digunakan sebagai alat praktikum Mahasiswa Jurusan Teknik Mesin Sekolah Tinggi Teknologi Industri Bontang. Hasil penelitian menunjukkan adanya pengaruh jumlah sudu terhadap kinerja prototype turbin air: (1) Kecepatan tangensial maksimum terjadi pada jumlah sudu 14 dengan nilai $12.769 \mathrm{rad} / \mathrm{s}$ dan kecepatan tangensial terendah terjadi pada jumlah sudu 18 dengan nilai $12.141 \mathrm{rad} / \mathrm{s}$. (2) Nilai daya hidrolis pada penelitian ini 2.64 Watt. (3) Nilai daya kinetik pada penelitian ini 3.886 Watt. (4) Daya turbin maksimum terjadi pada jumlah sudu 14 dengan nilai daya turbin 112.262 Watt, kemudian daya turbin terendah terjadi pada jumlah sudu 18 dengan nilai 99.141 Watt. (5) Daya generator listrik maksimum terjadi pada jumlah sudu 14 dengan nilai daya generator listrik sebesar 0.736 Watt. Sedangkan daya generator listrik terendah terjadi pada jumlah sudu 18 dengan nilai daya generator listrik sebesar 0.661 Watt. (6) Efisiensi turbin maksimum terjadi pada jumlah sudu 14 dengan nilai efisiensi turbin $28.888 \%$. Efisiensi turbin terendah terjadi pada jumlah sudu 18 dengan nilai efisiensi turbin $25.512 \%$. (7) Efisiensi generator listrik maksimum terjadi pada jumlah sudu 14 dengan nilai generator listrik $0.736 \%$. Efisiensi generator listrik terendah terjadi pada jumlah sudu 18 dengan nilai efisiensi turbin $0.661 \%$.
\end{abstract}

Kata Kunci: Analisis, jumlah sudu, kinerja, turbin pelton.

\section{PENDAHULUAN}

Energi air dapat dimanfaatkan sebagai pembangkit listrik dengan memanfaatkan tenaga potensial yang tersedia (potensi air terjun dan kecepatan aliran) [1]. Turbin air adalah salah satu mesin penggerak yang mana fluida kerjanya adalah air yang dipergunakan langsung untuk memutarkan roda turbin. Pada roda turbin terdapat sudu dan fluida kerja mengalir melalui runag di antara sudu tersebut [2].
Turbin pelton merupakan turbin impuls, yaitu turbin yang digerakkan oleh energi kinetik air. Semprotan air yang berkecepatan tinggi mengenai sudu dan setelah menggerakkan runner air keluar pada kecepatan rendah, yang berarti sebagian energinya tidak diserap oleh runner. Tekanan air masuk dan keluar sudu adalah tekanan atmosfir [3].

Laboratorium merupakan tempat untuk melatih mahasiswa dalam hal keterampilan melakukan praktek, 
demonstrasi, percobaan, penelitian dan pengembangan ilmu pengetahuan. Keberadaan laboratorium sebagai tempat praktikum sangat diperlukan untuk meningkatkan keterampilan mahasiswa. Pelaksanaan kegiatan praktikum dilakukan dalam pemberian pengalaman belajar kepada mahasiswa, supaya mahasiswa dapat berinteraksi dengan bahan - bahan pelajaran dan pengamatan gejala secara langsung yang terjadi pada alat uji turbin air tersebut. Kegiatan praktek di laboratorium dapat meningkatkan keterampilan mahasiswa apabila digunakan secara efisien, karena dengan praktek mahasiswa dapat memahami mata kuliah yang memerlukan penghayatan kongkrit dengan melakukan kegiatan nyata melalui praktek [4].

Penelitian turbin air yang telah dilakukan oleh penulis Tahun 2016 tentang kinerja turbin air kinetik poros vertikal. Penelitian sejenis yang dilakukan oleh penulis Tahun 2017 dengan variasi bentuk sudu terhadap torsi dan daya turbin air dan variasi diameter nosel turbin dengan metode pengereman putaran turbin. Penelitian lanjutan ini dengan memodifikasi prototype turbin air yang dirancang dan dibuat oleh penulis sebelumnya (tahun 2017) dengan metode yang berbeda dari penelitian tahun 2017 sehingga dapat menjelaskan bagaimana kinerja dari prototype turbin air pelton yang telah dimodifikasi apabila menggunakan variasi jumlah sudu turbin. Jumlah sudu turbin sangat menentukan putaran turbin sehingga dapat meningkatkan kinerja turbin. Untuk itu maka penelitian ini diarahkan untuk menentukan jumlah sudu yang tepat untuk menghasilkan kinerja turbin pelton yang maksimal [10].

\section{TINJAUAN PUSTAKA}

Turbin air adalah merupakan mesin penggerak yang merubah energi potensial menjadi energi mekanik dengan air sebagai fluida kerjanya. Menurut sejarahnya turbin hidrolik sekarang berasal dari dari kincirkincir air pada jaman abad pertengahan yang dipakai untuk memecah batu bara, keperluan pabrik gandum, dan lain-lain [5].
Berdasarkan perubahan energi turbin air dibedakan menjadi dua kelompok yaitu turbin impuls dan turbin reaksi.

\section{Turbin impuls}

Turbin impuls disebut juga dengan turbin air tekanan sama karena tekanan air yang keluar dari nossel tekanannya sama dengan tekanan atmosfir sekitarnya. Sehingga energi tempat dan energi tekanan yang dimiliki oleh aliran air dirubah semuanya menjadi energi kecepatan. Contoh dari turbin impuls ini adalah turbin pelton yang merupakan jenis turbin yang dibuat menjadi objek penelitian penulis [7].

Turbin air pelton adalah sebuah alat berbentuk lingkaran yang dibangun di sungai yang mempunyai debit air kecil tetapi mempunyai head yang tinggi. Alat ini berputar pada sumbunya karena adanya dorongan aliran air melalui pipa pesat yang cukup cepat. Sejalan dengan berputarnya turbin, alat ini sekaligus mengambil air dari sungai dan ditampung dalam sebuah bak penampung, selanjutnya dialirkan melalui sebuah pipa pesat dan dikeluarkan melewati sebuah nossel [7].

2. Turbin Reaksi

Turbin Reaksi adalah turbin yang memanfaatkan seluruh energi (energi potensial, kinetik, dan tekanan) untuk menghasikan energi kinetik di sudu. Sudu pada turbin reaksi mempunyai profil khusus yang menyebabkan terjadinya penurunan tekanan air selama melalui sudu. Perbedaan tekanan ini memberikan gaya pada sudu sehingga runner (bagian turbin yang berputar) dapat berputar. Turbin yang bekerja berdasarkan prinsip ini dikelompokkan sebagai turbin reaksi. Runner turbin reaksi sepenuhnya tercelup dalam air dan berada dalam rumah turbin. Pada pengujian turbin air hasil yang diharapkan adalah mendapatkan kinerja turbin [6].

Proses perhitungan untuk mendapatkan kinerja turbin dengan menggunakan persamaan berikut $[3][6][8][9]$ : 
1. Luas Penampang ujung nosel (A)

Persamaan untuk menghitung luas ujung nosel yang menumbuk sudu turbin digunakan persamaan/rumus 1 :

$$
A=\frac{1}{4} \cdot \pi \cdot d^{2}
$$

Dengan:

$$
\begin{aligned}
& A=\text { Luasan ujung nosel }\left(\mathrm{m}^{2}\right) . \\
& D=\text { diameter dalam nosel }(\mathrm{m})
\end{aligned}
$$

2. Kapasitas Aliran (Q)

Untuk menghitung kapasitas aliran, digunakan persamaan 2:

$$
Q=A \cdot v
$$

Dengan:

$$
\begin{aligned}
& Q=\text { Debit aliran air }\left(\mathrm{m}^{3} / \mathrm{s}\right) . \\
& \mathrm{A}=\text { Luasan ujung nosel }\left(\mathrm{m}^{2}\right) . \\
& v=\operatorname{Kecepatan} \text { aliran }(\mathrm{m} / \mathrm{s}) .
\end{aligned}
$$

3. Kecepatan Aliran (v)

Untuk menghitung kecepatan aliran, digunakan persamaan 3:

$$
v=\frac{Q}{A}
$$

Dengan:

$v=$ Kecepatan aliran $(\mathrm{m} / \mathrm{s})$

$Q=$ Debit aliran air $\left(\mathrm{m}^{3} / \mathrm{s}\right)$.

$\mathrm{A}=$ Luasan ujung nosel $\left(\mathrm{m}^{2}\right)$.

4. Laju Massa Air yang Mengalir $(\dot{m})$

Untuk menghitung massa aliran digunakan persamaan 4:

$$
\dot{m}=\rho . Q
$$

Dengan:

$$
\begin{aligned}
\dot{m} & =\text { Laju aliran massa air }(\mathrm{kg} / \mathrm{s}) \\
\rho & =\text { Massa jenis air }\left(\mathrm{kg} / \mathrm{m}^{3}\right) . \\
Q & =\text { Debit aliran air }\left(\mathrm{m}^{3} / \mathrm{s}\right) .
\end{aligned}
$$

5. Kecepatan anguler/tangensial ( $\omega$ )

Untuk mendapatkan nilai kecepatan anguler menggunakan persamaan 5:

$$
\omega=\frac{2 \cdot \pi \cdot n}{60}
$$

Dengan:

$\omega=$ Kecepatan anguler/tangensial $(\mathrm{rad} / \mathrm{s})$

$\mathrm{n}=$ Putaran turbin (rpm)

6. Perhitunga Daya:

a. Daya Hidrolis; $\mathrm{Ph}$ (Watt) adalah daya yang masuk ke nosel,besarnya dapat diukur dengan persamaan 6 yaitu :

$$
P_{h}=\rho \cdot g \cdot Q \cdot H
$$

Dengan:

$$
P_{h}=\text { Daya hidrolis (Watt) }
$$

$$
\begin{aligned}
\rho= & \begin{array}{l}
\text { Massa jenis air 996,74 } \\
\left(\mathrm{kg} / \mathrm{m}^{3}\right)
\end{array} \\
g= & \begin{array}{l}
\text { Gaya grafitasi bumi, 9,81 } \\
\left(\mathrm{m} / \mathrm{s}^{2}\right)
\end{array} \\
Q= & \text { Debit aliran air }\left(\mathrm{m}^{3} / \mathrm{s}\right) \\
H= & \text { head turbin }(\mathrm{m})
\end{aligned}
$$

b. Daya Kinetik jet air ; $P_{k}$ (Watt) dihitung dengan menggunakan persamaan 7 :

$$
\mathrm{P}_{k}=\frac{1}{2} \cdot \rho \cdot A \cdot v^{3}
$$

Dengan:

$\mathrm{P}_{\mathrm{k}}=$ Daya kinetis air (Watt).

$\rho=$ Massa jenis air 996,74 $\left(\mathrm{kg} / \mathrm{m}^{3}\right)$

$A=$ Luas penampang nosel turbin $\left(\mathrm{m}^{2}\right)$

$v=\operatorname{Kecepatan}$ aliran $(\mathrm{m} / \mathrm{s})$

c. Daya Turbin; $P_{t}$ (Watt) dihitung dengan persamaan 8 :

$$
P_{t}=\rho \text {. A. } \omega .(\omega-v) \cdot(1+\cos \theta) \cdot v
$$

Dengan:

$\mathrm{P}_{\mathrm{t}}=$ Daya turbin air (Watt).

$\rho=$ Massa jenis air 996,74 $\left(\mathrm{kg} / \mathrm{m}^{3}\right)$

$A=$ Luas penampang nosel turbin $\left(\mathrm{m}^{2}\right)$

$\omega=$ Kecepatan anguler $/$ tangensial $(\mathrm{rad} / \mathrm{s})$

$v=$ Kecepatan aliran $(\mathrm{m} / \mathrm{s})$

$\cos \theta=$ Sudut pancaran air (posisi nosel)

d. Daya Listrik (Daya Generator); $P g$ (Watt) dihitung dengan persamaan 9 :

$$
P_{g}=\text { V.I. Cos } \phi
$$

Dengan:

$$
\begin{aligned}
\mathrm{Pg}_{\mathrm{g}} & =\text { Daya Generator (Watt) } \\
\mathrm{V} & =\text { Tegangan listrik (Volt) } \\
\mathrm{I} & =\text { Arus listrik (Ampere) } \\
\operatorname{Cos} \phi & =\text { Faktor daya (derajat) }
\end{aligned}
$$

7. Perhitungan Efisiensi:

a. Efisiensi SuduTurbin ; $\eta t$

$$
\eta_{t}=\frac{P_{t}}{P_{k}} x 100 \%
$$

Dengan:

$\eta_{\mathrm{t}}=$ Efisiensi turbin air $(\%)$

$\mathrm{P}_{\mathrm{t}}=$ Daya turbin (Watt)

$\mathrm{P}_{\mathrm{k}}=$ Daya kinetik air (Watt) 
b. Efisiensi generator Turbin; $\eta_{s}$ menghitungnya menggunakan persamaan 11 :

$$
\eta_{g}=\frac{P_{g}}{P_{h}} x 100 \%
$$

Dengan:

$\eta_{\mathrm{g}}=$ Efisiensi generator turbin (\%)

$\mathrm{P}_{\mathrm{g}}=$ Daya generator turbin (Watt)

$\mathrm{P}_{\mathrm{h}}=$ Daya hidrolik air (Watt)

\section{METODE PENELITIAN}

Penelitian yang dilakukan menggunakan metode eksperimental dengan memodifikasi alat penelitian sebelumya berskala laboratorium seperti ditunjukkan pada Gambar 1. Penelitian ini bertempat di Bontang dan waktu penelitian dilakukan pada Bulan Mei 2018 dengan pengujian jumlah sudu turbin yang digunakan serta bentuk peralatan penelitian ditunjukkan pada Gambar 1 dengan ukuran alat penelitian yaitu panjang $110 \mathrm{~cm}$, lebar 60 $\mathrm{cm}$, dan tinggi $40 \mathrm{~cm}$ yang terbuat dari besi plat siku. Ukuran bak penampung air sebesar $60 \mathrm{~cm} \times 60 \mathrm{~cm}$ yang terbuat dari lembaran plat besi dengan ketebalan $0,3 \mathrm{~cm}$. Ukuran runner turbin berdiameter $33,4 \mathrm{~cm}$. Sedangkan ukuran poros turbin berdiameter $2,54 \mathrm{~cm}$ dengan panjang porosnya $80 \mathrm{~cm}$.

\section{Variabel Penelitian}

Variabel yang digunakan pada penelitian ini ada tiga yaitu variabel bebas, variabel terikat dan variabel terkontrol.

a. Variabel Bebas

Variabel bebas pada penelitian ini terdiri dari:

1. Debit air : $0,0005 \mathrm{~m}^{3} / \mathrm{s}$

2. Jumlah Sudu turbin 18,16 , dan 14 buah

3. Sudu turbin berbentuk mangkuk.

b. Variabel Terkontrol

1. Sudut sudu dikondisikan konstan pada posisi $90^{\circ}$.

2. Ukuran Nosel turbin $1 / 2$ inchi

c. Variabel Terikat

Variabel terikat pada penelitian ini adalah kecepatan anguler/tangensial, daya hidrolis air, daya kinetik air, daya turbin, daya generator listrik, efisiensi turbin dan efisiensi generator listrik.

\section{Prosedur Penelitian}

Adapun prosedur pengujian untuk pengambilan data penelitian yaitu sebagai berikut:

1. Membuat tabel untuk mencatat hasil pengujian,

2. Menyiapkan dan memasang semua instalasi penelitian beserta alat ukur yang digunakan,

3. Memasang nosel ukuran $1 / 2$ Inch sesuai yang ditentukan,

4. Memasang jumlah sudu 18 buah terlebih dahulu untuk pengambilan data pertama,

5. Mengecek semua komponen turbin yang diteliti untuk memastikan kesiapan sebelum mulai menghidupkan pompa air dan pastikan semua kondisi alat ukur dalam keadaan baik,

6. Tekan saklar/tombol untuk menghidupkan pompa air,

7. Mengukur debit aliran air dengan menggunakan alat ukur flowmeter dan mencatat hasil pengukurannya,

8. Mengukur putaran poros turbin dan putaran poros generator dengan alat ukur tachometer kemudian mencatat nilai rpm pada alat ukur tachometer,

9. Mengukur tegangan output dan arus output pada generator turbin dan mencatat nilai tegangan dan arus pada alat ukur multitester,

10. Mengulang langkah pengambilan data mulai nomor empat dengan memasang jumlah sudu 16 dan 14 sampai langkah pengambilan data nomor sembilan,

11. Mengolah dan menganalisa data penelitian yang didapatkan untuk mengetahui nilai kinerja turbin air yang diteliti,

12. Menyimpulkan hasil penelitian yang dilakukan.

\section{Instalasi Alat Penelitian}

Pada penelitian ini alat pengujian yang digunakan adalah turbin air jenis pelton poros horizontal yang telah dibuat sebagai alat praktikum mahasiswa teknik mesin, bentuk instalasi penelitian seperti ditunjukkan pada Gambar 1. 


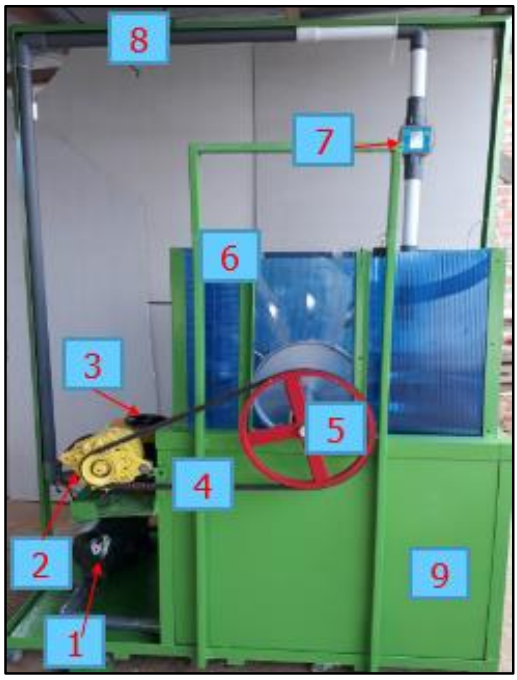

Gambar 1. Instalasi Penelitian.

Keterangan Gambar 1:

1. Pompa air

2. Generator lisrtrik

3. Accu 12 Volt

4. $\quad$-belt

5. Pulley

6. Rangka istalasi turbin

7. Alat ukur flowmeter

8. Pipa PVC 1 inchi

9. Bak penampung air

\section{HASIL DAN PEMBAHASAN}

\section{Data Hasil Penelitian}

Pengujian ini dilakukan untuk mendapatkan data putaran turbin, putaran generator, tengangan output listrik, arus output listrik, head turbin, debit aliran. Data penelitian seperti ditunjukkan pada Tabel 1.

Tabel 1. Data pengujian turbin pelton

\begin{tabular}{|c|c|c|c|c|c|c|}
\hline 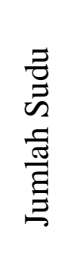 & 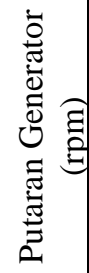 & 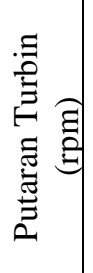 & 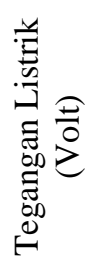 & 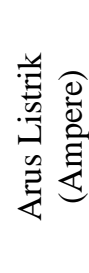 & 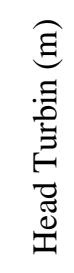 & 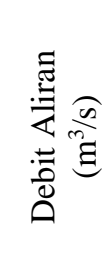 \\
\hline 18 & 417 & 116 & 3,42 & 0,58 & 0,54 & 0,0005 \\
\hline 16 & 420 & 119 & 3,51 & 0,61 & 0,54 & 0,0005 \\
\hline 14 & 439 & 122 & 3,56 & 0,62 & 0,54 & 0,0005 \\
\hline
\end{tabular}

\section{Hasil Pengolahan Data dan Pembahasan Hasil Penelitian}

Teknik analisa data menggunakan teknik deskriptif berdasarkan hasil penelitian yang dilakukan, dari data pengujian lapangan yang dilakukan seperti pada Tabel 1 tersebut kemudian dilakukan pengolahan data atau perhitungan menggunakan rumus terapan seperti yang tercantum pada persamaan 1 sampai persamaan ke 11 dengan tujuan untuk mendapatkan nilai daya hidrolis, daya kinetik, kecepatan tangensial, daya turbin, daya generator listrik, efisiensi turbin, dan efisiensi generator seperti ditunjukkan pada Tabel 2 dan 3.

Tabel 2. Hasil pengolahan data turbin

\begin{tabular}{|c|c|c|c|}
\hline \multirow{2}{*}{ Jumlah Sudu } & \multicolumn{3}{|c|}{ Kinerja Turbin } \\
\cline { 2 - 4 } & $\mathrm{P}_{\mathrm{h}}$ (Watt) & $\mathrm{P}_{\mathrm{k}}$ (Watt) & $\begin{array}{c}\omega \\
(\mathrm{rad} / \mathrm{s})\end{array}$ \\
\hline 18 & 2.640 & 3.886 & 12.141 \\
\hline 16 & 2.640 & 3.886 & 12.455 \\
\hline 14 & 2.640 & 3.886 & 12.769 \\
\hline
\end{tabular}

Daya hidrolis perolehan dengan hitungan daya hidrolis turbin yang diteliti dihitung menggunakan persanmaan 6, dimana massa jenis air $(\rho)$ sebesar 996,74 $\mathrm{kg} / \mathrm{m}^{3}$, gaya gravitasi $(\mathrm{g})$ sebesar $9,81 \mathrm{~m} / \mathrm{s}^{2}$ dan head turbin didapat dari hasil pengukuran sebesar $0,54 \mathrm{~m}$. berdasarkan hasil perhitungan yang ditunjukkan pada pada Tabel 2 didapatkan nilai daya hidrilis sebesar 2,640 Watt. Daya kinetik jet air turbin yang diteliti dihitung dengan menggunakan persamaan 7 , dimana luas penampang nosel $(\mathrm{A})=1 / 4 \pi \mathrm{D}^{2}$ dengan diameter nosel $1 / 2$ inch atau $0,0127 \mathrm{~m}$ sehingga mendapatkan hasil perhitungan daya kinetik sebesar 3,886 Watt seperti ditunjukkan pada Tabel 2.

Kecepatan tangensial diperoleh dengan menghitung menggunakan persamaan 5, berdasarkan hasil perhitungan yang ditunjukkan pada pada Tabel 1 , nilai kecepatan tangensial turbin pada jumlah sudu 18 sebesar 12.141 Watt, pada jumlah sudu 16 kecepatan tangensial sebesar 12.455 Watt, sedangkan pada jumlah sudu 14 kecepatan tangensial sebesar 12.769 Watt. Berdasarkan nilai kecepatan tangensial dari variasi jumlah sudu didapat kecepatan tangensial turbin terbesar terjadi pada jumlah sudu 14, hal ini terjadi karena pada jumlah sudu 14 posisi pancaran air dari nosel tepat mengenai pertengahan sudu 
mangkuk sehingga menyebabkan putaran runner turbin meningkat dan mengakibatkan kecepatann tangensial meningkat.

Tabel 3. Hasil pengolahan data turbin

\begin{tabular}{|c|c|c|c|c|}
\hline \multirow{2}{*}{$\begin{array}{c}\text { Jumlah } \\
\text { Sudu }\end{array}$} & \multicolumn{4}{|c|}{ Kinerja Turbin } \\
\cline { 2 - 5 } & $\mathrm{P}_{\mathrm{t}}$ (Watt) & $\begin{array}{c}\mathrm{P}_{\mathrm{g}} \\
(\text { Watt) }\end{array}$ & $\begin{array}{c}\eta_{\mathrm{t}} \\
(\%)\end{array}$ & $\begin{array}{c}\eta_{\mathrm{g}} \\
(\%)\end{array}$ \\
\hline 18 & 99.141 & 1.746 & 25.512 & 0.661 \\
\hline 16 & 105.603 & 1.884 & 27.175 & 0.714 \\
\hline 14 & 112.262 & 1.942 & 28.888 & 0.736 \\
\hline
\end{tabular}

Dari data Tabel 3 tersebut kemudian dijadikan dalam bentuk grafik, pembuatan grafik bertujuan untuk melihat fenomena trending grafik kinerja turbin yang dilakukan dengan menggunakan bantuan Microsoft Office Excel. Hubungan antara da daya turbin, daya generator, efisiensi turbin dan efisiensi generator terhadap jumlah sudu yang diteliti seperti ditunjukkan Gambar 2 sampai 5.

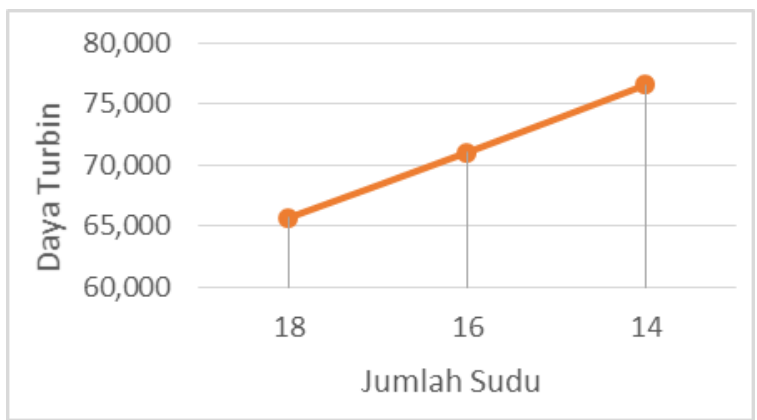

Gambar 2. Grafik hubungan jumlah sudu terhadap daya turbin

Daya turbin dipengaruhi oleh kecepatan air yang keluar dari nosel dan kecepatan air mempengaruhi gaya tangensial, apabila pancaran air dari nosel tepat mengenai pertengahan sudu mangkuk sehingga menyebabkan putaran runner turbin meningkat dan mengakibatkan kecepatann tangensial meningkat dan gaya tangensial mempengaruhi daya turbin air.

Berdasarkan hasil perhitungan yang ditunjukkan pada Tabel 3 dan berdasarkan grafik hubungan jumlah sudu terhadap daya turbin pada gambar 2, bahwa jumlah sudu mempengaruhi daya turbin nilai daya turbin pada jumlah sudu 18 sebesar 99.141 Watt, pada jumlah sudu 16 daya turbin sebesar 105.603 Watt. Sedangkan pada jumlah sudu 14 daya turbin sebesar 112.603 Watt.
Berdasarkan nilai daya turbin dari variasi jumlah sudu didapat daya turbin terbesar terjadi pada jumlah sudu 14.

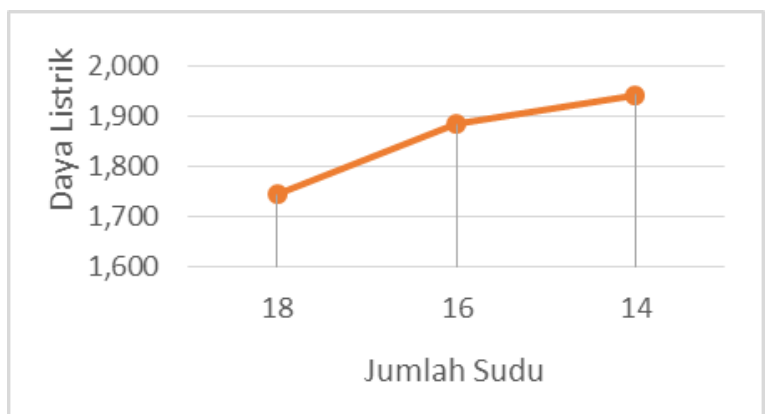

Tabel 3. Grafik hubungan jumlah sudu terhadap daya listrik

Daya listrik dipengaruhi oleh tegangan output dan arus output listrik yang dihasilkan oleh generator DC yang dipakai dan putaran generator dipengaruhi oleh putaran turbin, semakin tinggi putaran turbin maka putaran generator juga semakin tinggi hal ini terjadi karena pully pada poros turbin disambungkan dengan pully poros generator melalui $V$-belt sehingga dapat mentrasnfer putaran. Berdasarkan hasil perhitungan yang ditunjukkan pada pada Tabel 3, nilai daya generator pada jumlah sudu 18 sebesar 1.746 Watt, pada jumlah sudu 16 daya generator sebesar 1,884 Watt. Sedangkan pada jumlah sudu 14 daya generator sebesar 1.942 Watt. Berdasarkan nilai daya generator dari variasi jumlah sudu didapat daya generator turbin terbesar terjadi pada jumlah sudu 14.

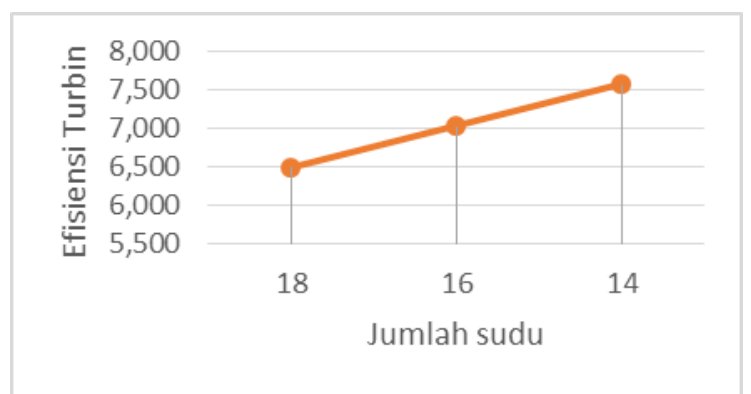

Gambar 4. Grafik hubungan jumlah sudu terhadap efisiensi turbin

Efisiensi turbin dipengaruhi oleh daya turbin dan daya kinetik air, semakin tinggi daya turbin maka efisiensi turbin juga semakin tinggi. Dari hasil perhitungan yang ditunjukkan pada Tabel 3, nilai efisiensi turbin pada jumlah sudu 18 sebesar $25.51 \%$, 
pada jumlah sudu 16 efisiensi turbin sebesar $27.17 \%$ sedangkan pada jumlah sudu 14 efisiensi turbin sebesar $28.89 \%$. Berdasarkan nilai efisiensi dari variasi jumlah sudu didapat efisiensi turbin terbesar terjadi pada jumlah sudu 14 .

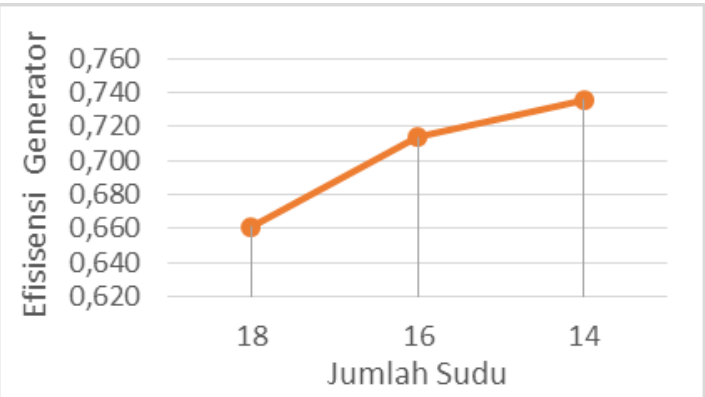

Gambar 5. Grafik hubungan jumlah sudu terhadap efisiensi generator

Efisiensi generator dipengaruhi oleh daya generator dan daya hidrolis, semakin tinggi generator maka efisiensi generator juga semakin tinggi. Dari hasil perhitungan yang ditunjukkan pada Tabel 3, nilai efisiensi generator pada jumlah sudu 18 sebesar $0.66 \%$, pada jumlah sudu 16 efisiensi generator sebesar $0.71 \%$ sedangkan pada jumlah sudu 14 efisiensi generator sebesar $0.74 \%$. Berdasarkan nilai efisiensi generator dari variasi jumlah sudu didapat efisiensi generator terbesar terjadi pada jumlah sudu 14 .

\section{KESIMPULAN}

Hasil penelitian menunjukan adanya pengaruh jumlah sudu terhadap kinerja prototype turbin air, sehingga dapat disimpulkan bahwa:

1. Kecepatan tangensial maksimum terjadi pada jumlah sudu 14 dengan nilai $12.769 \mathrm{rad} / \mathrm{s}$ dan kecepatan tangensial terendah terjadi pada jumlah sudu 18 dengan nilai $12.141 \mathrm{rad} / \mathrm{s}$,

2. Nilai daya hidrolis pada penelitian ini 2.64 Watt,

3. Nilai daya kinetik pada penelitian ini 3.886 Watt,

4. Daya turbin maksimum terjadi pada jumlah sudu 14 dengan nilai daya turbin 112.262 Watt, kemudian daya turbin terendah terjadi pada jumlah sudu 18 dengan nilai 99.141 Watt,

5. Daya generator listrik maksimum terjadi pada jumlah sudu 14 dengan nilai daya generator listrik sebesar 0.736 Watt. Sedangkan daya generator listrik terendah terjadi pada jumlah sudu 18 dengan nilai daya generator listrik sebesar 0.661 Watt,

6. Efisiensi turbin maksimum terjadi pada jumlah sudu 14 dengan nilai efisiensi turbin $28.888 \%$. Efisiensi turbin terendah terjadi pada jumlah sudu 18 dengan nilai efisiensi turbin $25.512 \%$,

7. Efisiensi generator listrik maksimum terjadi pada jumlah sudu 14 dengan nilai generator listrik $0.736 \%$. Efisiensi generator listrik terendah terjadi pada jumlah sudu 18 dengan nilai efisiensi turbin $0.661 \%$.

\section{REFERENSI}

[1]. Irawan, D. (2014). PROTOTYPE TURBIN PELTON SEBAGAI ENERGI

ALTERNATIF MIKROHIDRO DI LAMPUNG. Turbo: Jurnal Program Studi Teknik Mesin, 3(1).

[2]. Arismunandar, W. (2004). Penggerak mula turbin, edisi kitiga ITB, Bandung.

[3]. Hamidi. Supandi. Dan Rohermanto, A, (2006). "Rancang Bangun Model Turbin Pelton Mini Sebagai Media Simulasi/Praktikum Matakuliah Konversi Energi dan Mekanika Fluida" Jurnal Ilmiah Semesta Teknika, Jurusan Teknik Mesin Politeknik Negeri Pontianak.

[4]. Dharma, U. S., \& Prasetyo, G. (2012). PENGARUH PERUBAHAN LAJU ALIRAN TERHADAP TEKANAN DAN JENIS 
ALIRAN YANG TERJADI

PADA ALAT UJI

PRAKTIIKUM

MEKANIKA

FLUIDA. Turbo: Jurnal

Program Studi Teknik

Mesin, 1(2).

[5]. Susatyo, A. dan Hakim, L (2003) perancangan turbin pelton. Prosiding Seminar Nasional tanggal 29 - 30 Juni, pusat penelitian informatika-LIPI. Bandung

[6]. Yani. A, Mihdar dan Erianto. R (2016) "Pengaruh variasi bentuk sudu terhadap Kinerja Air turbin kinetik" (Sebagai Pembangkit Listrik Daerah Pedesaan). Jurnal Turbo No. 1 Volume 5. Jurusan Teknik Mesin Fakultas Teknik Universitas Muhammadiyah Metro - Lampung.

[7]. Thobari. A, Mustaqim, dan Wibowo H, (2013) "Analisa Pengaruh Sudut Keluar Sudu Terhadap Putaran Turbin Pelton" Jurnal ilmiah Faculty of Engineering, Universitas Pancasakti Tegal.

[8]. Yani, A. (2017). RANCANG BANGUN ALAT PRAKTIKUM TURBIN AIR DENGAN PENGUJIAN BENTUK SUDU TERHADAP TORSI DAN DAYA TURBIN YANG DIHASILKAN. Turbo: Jurnal Program Studi Teknik Mesin, 6(1).

[9]. Rosmiati, R., \& Yani, A. (2017). PENGARUH VARIASI DIAMETER NOSEL TERHADAP TORSI DAN DAYA TURBIN AIR. Turbo: Jurnal Program Studi Teknik Mesin, 6(1).
[10]. Yani, A., Mustafa, D., \& Taqwa, T. (2018). RANCANG BANGUN PROTOTYPE PEMBANGKIT LISTRIK TENAGA UAP MINI SEBAGAI MEDIA PRAKTIKUM MAHASISWA. Turbo: Jurnal Program Studi Teknik Mesin, 7(1). 